\title{
WALUCHOW'S LIVING-TREE CONSTITUTIONALISM. INTRODUCTION
}

\section{Brian BURGE-HENDRIX}

This section comprises a set of articles responding to Wilfrid Waluchow's book A Common Law Theory of Judicial Review: The Living Tree. ${ }^{1}$ With the exception of Stuchiner and Schecaira, all of the authors were participants in a special workshop on Waluchow's book, held in Krakow as part of the 23rd IVR World Congress. ${ }^{2}$ The subject of A Common Law Theory of Judicial Review makes for a particularly interesting and bold book by someone already acknowledged as being expert in the fine-grained, highly abstract realms of legal theory. Though readers of Waluchow's Inclusive Legal Positivism ${ }^{3}$ will recognize his methodological approach to law as forming part of the background to his latest book, $A$ Common Law Theory of Judicial Review directly engages in substantive issues of law and politics, taking its examples from concrete areas such as Canadian constitutional adjudication, areas in which the highly theoretical work of legislators, lawyers, judges, and philosophers takes place in a

1 Waluchow, W. J., A Common Law Theory of Judicial Review: The Living Tree, Cambridge, Cambridge University Press, 2007.

2 The success of that workshop is evinced by the quality of the papers here, and as organizer of the workshop I would like to thank the original participants, as well as Noel Struchiner and Fábio Perin Schecaira, and Professor Waluchow for their excellent work and willingness to engage with each other in a critical yet congenial fashion. Thanks are due, also, to the editors of Problema for their work in seeing these articles through to publication.

3 Waluchow, W. J., Inclusive Legal Positivism, Oxford, Clarendon Press, 1994. 
living social realm with practical consequences of the highest order.

It is not surprising, then, that the responses to Waluchow range over methodological issues in legal and moral philosophy, methodologies of judicial review and of legislating, aspects of democratic theory (including the justification of democracy itself), evaluations of the current state of popular politics, and legal, moral, and political rights. Reference is also made to particular legal cases to test Waluchow's theory. You, the reader, are presented with many different angles of approach and evaluative techniques with which to make your decision about the veracity, benefits, and shortcomings of Waluchow's account of an up-and-coming means of judicial and political practice. The debates are vital ones, suitable for considering the notion of living-tree constitutionalism itself.

The evocative main title of Tom Campbell's response - "Slaying the Hydra" - aptly indicates his scepticism with regard to Waluchow's living-tree constitutionalism as well as Campbell's own stated preference for a prescriptive legal positivism that eschews entrenched Charters and Bills of Rights. ${ }^{4}$ Campbell attacks living-tree constitutionalism primarily by describing its "potentially extreme consequences for the authority of elected governments." (22) The most fearsome scenario he sketches is one where living-tree constitutionalism leads to a form of judicial review whereby judges are granted "an extraordinarily open-ended power that can be effectively limited neither by Charter amendment nor parliamentary override." (22) Thus, while Campbell recognizes the congruence of Waluchow's approach with the actual uses of Charters in the present-day, and so acknowledges the descriptive veracity of living-tree constitutionalism as applied to many jurisdictions, Campbell none-

4 See Campbell, The Legal Theory of Ethical Positivism, Aldershot, Ashgate Publishing, 1996, and Campbell, Prescriptive Legal Positivism: Law, Rights and Democracy, London, University College London Press, 2004. 
theless finds the general approach to be morally and politically unsound.

Although the "Monster", to use Campbell's term, offers no unduly optimistic guarantee that living-tree constitutionalism can guarantee Charter rights, and purports more humbly to provide the best means for gradually precisifying necessarily vague statements of abstract, general rights, we ought to take the appearance of its cloak of humility as cause for alarm. While Waluchow's refusal to resort to the stock claim that judicial review is merely protecting explicit, clear rights against legislative tyranny means that he rightly takes seriously the uncertain character of Charter rights (as do all the authors of the articles in this section), his acceptance of that uncertainty entails that living-tree constitutionalism promotes, according to Campbell, a form of judicial review that is radically unconstrained and commensurably dangerous: the monster's humble approach "also removes the formal constraints of the text of a Charter of Rights on the use of judicial discretion in the exercise of judicial review through the application of what, in the theory, seen as indeterminate statements of ill-defined values." (24) In short, Campbell suggests that Waluchow's sincere admission of moral uncertainty with regard to Charter rights ought to lead us to conclude that practices of judicial review which appeal to those same rights will always have the appearance of being guided by the rights themselves even when, inevitably, those practices are not actually constrained by them. Hence the humble Monster is especially sneaky, unaware, perhaps, of the full consequences of simultaneously espousing Charter rights while sincerely taking note of their inherent indeterminacy.

Campbell and Waluchow greatly differ on the possibility of resolving "fundamental value disagreement" (25), a difficult hurdle which living-tree constitutionalism must overcome if it is to serve as a reply to Jeremy Waldron's forceful attacks on the legitimacy of judicial review. However, even the existence of an actual (though implicit) consensus on 
deep values in a particular jurisdiction would not assuage Campbell's fear of the Monster behind the bench, for he points out that, even if living-tree constitutionalism presents a workable methodology for judicial interpretation or specification of Charters, "there is no way of ensuring that the judges exercising these powers accept this view of their constitutional methodology... [and] even if they do seek to follow Waluchow's model, there is no way of knowing if they are successful in discovering what this constitutional morality consists of." (26)

The Monster, as Campbell sees it, is also dangerous when it becomes proud. Although some of the responses to living-tree constitutionalism find plausible Waluchow's claim that, in the relevant circumstances of Charter application, courts can be better decision-makers (or at least can place themselves in better decision-making circumstances) than legislators, Campbell takes the opposite view: "Waluchow's thesis that courts are good surrogates for, or exemplars of, deliberative democracy is questionable, with respect to the quality of reasoning found in law reports, the procedures actually followed in reaching judicial decisions, and the competencies attributed to courts." (27) Economic and institutional independence does not equate to impartiality, hence the apparent guarantees of independence for the judiciary (in some jurisdictions) should not lead us to assume that impartial decision-making, especially impartial moral reasoning, is guaranteed thereby. Even the specialized expertise of judges with vast experience of publicly reasoning in the courtroom, trying difficult and complex cases while skillfully using equally difficult and complex modes of reasoning, is turned by Campbell from a benefit to Charter considerations (on Waluchow's account) to the detriment of those most in need of legal protection: "Inevitably a case-based approach gives priority attention to the interests of the parties to the case in question rather than other individuals or groups within society as a whole, and do so in a sphere where wealth and technical expertise tends to domi- 
nate." (28) However excellent judicial reasoning about Charter rights may be, the institutional setting in which such reasoning occurs is not inherently egalitarian nor always accessible to all members of society. A proud Monster may fail to recognize the many potential cases it does not have the opportunity to adjudicate, and so its decisions may have consequences beyond the realm of its experiential horizon, or so Campbell suggests.

Campbell's informed contrarianism is also evident when he turns on its head the oft-heard claim that Charters protect vulnerable minorities against powerful majorities. What of the opposite problem, namely "the protection of vulnerable majorities against powerful minorities"? (31) - especially those minorities whose wealth or access to legal expertise enable them to load the dockets with Charter cases.

Finally, it is worth noting Campbell's positive suggestion: that "the best solution to the need for constitutional updating is to make them subject to the normal legislative processes of amendment change." (32) That intriguing claim shows, I think, how the temporal and cultural breadth of Waluchow's project seems to inspire equally wide-ranging counterexamples, alternatives, and modifications to living-tree constitutionalism-Campbell's discussion of "common-law positivism" is a fine example of these.

Imer Flores' thoroughgoing response to living-tree constitutionalism provides a broad survey of the relevant literature and is in general agreement with Waluchow's project, though from Flores' perspective it encompasses a theory of constitutional democracy and constitutionalism more generally rather than its more humble claim to be a theory of judicial review. Waluchow's Copernican turn, Flores believes, is in fact "capable of reconciling two competing needs: fixity and flexibility." (40) Largely sympathetic to living-tree constitutionalism, Flores' response nonetheless proposes a friendly amendment after a detailed consideration of its features. 
While approving of the metaphor of the living tree, Flores makes an important observation regarding the unpredictable paths living-tree constitutionalism may take once put in practice. A constitution and its attendant social practices, including the practice of judicial review, is not to be confused with a machine, something that can be started and stopped at will; rather, a constitutionalism of the type espoused by Waluchow "has a life of its own and so is capable of (re)acting in different unexpected and unforeseen ways." (41) Replacing the parts or redirecting the actions of a machine is largely an activity founded on prediction, but organic entities like living trees are nurtured and, when necessary, given transplants such that the consequences of development and intervention are far less predictable.

Like some of the other responders, Flores discerns a Dworkinian flavour in the courts' development and reasoning regarding Charters (although Waluchow, in his reply, is at pains to distinguish his notion of "constitutional morality" from Dworkin's background principles of "political morality"). And, more forcefully than others, Flores goes out of his way to question the descriptive accuracy of the positivist roots of Waluchow's account (see Flores, footnote 7 at 43). These observations are made in the second section of Flores' response where he brings to bear a wide variety of illuminating cases and other sources.

A main intuition on the part of Flores, and one he explicates at length, concerns the difference between a bottom-up and a top-down account of judicial methodology. The former is often equated with a paradigmatic common law system such as that of Great Britain; the latter is usually assigned to civil law systems where the notion of judge-made law is more expressly eschewed. Flores is concerned to show that this typical descriptive apportionment is misleading, especially given the presence of Charters in non-common law countries, in regional courts, and in civil law jurisdictions subsisting within a more generally common law one. (55) Accordingly, Flores notes that "it is clear 
that the differences between the common law and the civil law systems, together with their respective methodologies, tend to be exaggerated, overdrawn and overstated, whilst both systems are getting closer and resemble each other more every day." (55) Thus, from both descriptive and practical perspectives, the use of the term "common law methodology" may be misleading. Flores goes on to distinguish between "common law" construed as judge-made law, the custom of the realm, and common reason. (56)

Waluchow's reply defends his use of the term "common law", or at least disambiguates it by pointing to definitions offered in A Common Law Theory of Judicial Review, yet there remains the deeper issue of whether the bottom-up methodology is an apt description of the judicial practices of living-tree constitutionalism. As he has in other works, Flores champions the importance of legisprudence and the role of legislators, a position which Tom Campbell would likely have sympathy with. We might wonder, then, how Waluchow's theory will look once it is expanded to take full account of the role of legislatures within Charter societies. Again, we see how what purports to be a theory of judicial review inspires "digressions" which suggest that a larger, more encompassing legal-philosophical tree has yet to reach its full potential. Flores ultimately aims to amend Waluchow's theory such that the branches of the tree attain "a complex balance not only between fixity and flexibility but also between fallibility and finality." (64) This balance evokes a recurring theme in this series of papers: the notion that courts and legislatures in Charter systems are or can be engaged in a dialogue with each other.

Kenneth Einar Himma directly cuts to the a central problem in any theory of constitutional interpretation, and finds that "Waluchow does not fully engage the issue of whether the right to self-governance is violated by judicial review." (86) In this regard, then, Himma holds that the influential anti-judicial review argument of Waluchow's primary opponent, Jeremy Waldron, stands firm. Readers will of course 
examine Waluchow's reply and determine for themselves whether living-tree constitutionalism is compatible with a viable and acceptable right to self-governance, but in any event Himma's critical encounter with A Common Law Theory of Judicial Review merits serious consideration.

Himma initially champions Waldron's position by foregrounding the practice of judicial review in the United States and the force of declarations of unconstitutionality - laws declared unconstitutional are thought to have no validity, not just from the moment of their being declared unconstitutional, but from the moment of their enactment as (purported) law. The status of such declarations arguably mirrors the Canadian one, where unconstitutional laws are deemed to be "of no force and effect" ab initio. ${ }^{5}$ Yet Himma goes on to base his argument largely on the context of the legal system of the United States, whose legal practices differ in some significant ways from those in Canada, most especially insofar as many American judges are elected rather than appointed, hence must be concerned with their own re-election; the U.S. also lacks the so-called "notwithstanding clause" that exists in Canada, whereby a legislature can pass and render immune to judicial review (for a set period of time, albeit renewable) legislation that infringes Charter rights.

By carefully explicating the right of self-governance - a central feature of any democratic theory or polity - Himma reinforces the fact that "there are moral limits on the extent to which any individual or set of individuals may use coercive measures to restrict the freedom of others" (80), notes the difficulty of grounding that right on a social consensus (yet another example of the problematizing effect putative

5 See Waluchow's discussion of the Morgentaler case in Inclusive Legal Positivism. Interestingly, Canadian courts' self-descriptions of the no-force-and-effect doctrine happen to run counter to the opinion of the leading Canadian expert on Canadian constitutional law, Peter Hogg, and the doctrine in fact a contestable descriptive claim among Canadian legal theorists; see Giudice, Michael, "Unconstitutionality, Invalidity, and Charter Challenges", Canadian Journal of Law and Jurisprudence 15, 2002, pp. 69-83, and the final chapter of Brian Burge-Hendrix, Epistemic Uncertainty and Legal Theory, Aldershot, Ashgate Publishing, 2008. 
consensuses play in the issues we are discussing), and directs us towards a plausible defence of judicial review in the face of the right to self-governance, namely a Lockean conception of the right whereby judicial declarations of invalidity fall one step short in force but are similar in character to the public's moral right to violent revolution in certain cases.

All of this makes clear why judicial review raises particularly heated controversies in the United States. If the living tree is to take root there, it must prepare itself for a difficult battle indeed. As Himma notes, Waluchow can offer a defence of judicial review - even the strong form found in the U.S. ${ }^{6}$ - insofar as the institution of judicial review is no more inherently anti-democratic than other forms of legitimately delegated authority. Himma, however, challenges the move from accepting the legitimacy of common-law methodology and legislative delegation to accepting judicial review as legitimate, on the grounds that (in some jurisdictions) the latter is not subject to legislative constraint. (8384) Himma notes that other points might be made in favour of judicial review, and is himself, and unlike Tom Campbell, hesitatingly accepting of at least the possibility of arguing that judicial decisions may "have the effect of raising the level of debate among legislatures and citizens in the U.S." (84) Regardless, Waldron's argument is founded on moral rights and good consequences are not sufficient justification (for most) when rights are violated.

By keeping distinct the matters of judicial review and judicial supremacy, Waluchow (according to Himma) avoids defending the very form of judicial review Waldron is most concerned to attack. Moroever, Himma finds that Waluchow mischaracterizes Waldron's position when claiming that Waldron is trapped in a Cartesian circle. Yet, ultimately, Himma offers insightful comments on American politics be-

6 Readers will note, however, that both in A Common Law Theory of Judicial Review and in his reply in this volume, Waluchow focuses on a weaker form of judicial review than that found in the U.S. 
fore concurring with Waluchow's claim that judges tend to make better decisions about the objective status of Charter rights in relation to legislation and other government actions. If that is the case, however, then shouldn't Waluchow go beyond defending a modest form of judicial review and suggest, instead, that judges ought to be given full authority to make important political decisions?

In her subtle yet powerful response to Waluchow, Natalie Stoljar also tries to push living-tree constitutionalism from its avowedly limited form with descriptive ambitions to a deeper constitutional methodology that is constructive/ ameliorative. Noting, like many of the other respondents, that A Common Law Theory of Judicial Review is nothing less than "a debate over the nature of democracies" (103), Stoljar suggests that what Waluchow describes as cases of epistemic failure are better described as substantive moral failures in the interpretation of Charter rights, in which case living-tree constitutionalism incorporates a strong form of autonomy with considerable moral significance.

Constitutional morality, according to Waluchow, is not necessarily the best objective account of morality, but rather is the best explanation of a Charter society's morality-constitutional morality successful on descriptive grounds even where the social morality is reprehensible and ought to be rejected, as in the case of apartheid-era South Africa. Thus Waluchow is able to counter Waldron's argument from disagreement by positing the existence (in most cases) of an overlapping consensus, thereby preventing disagreement from going "all the way down." Moreover, by striking down moral opinions which do not fit with the best explanation of social morality, courts do not violate autonomy in the way they must do were they to nullify authentic moral commitments; on the contrary, the courts use their discovery of constitutional morality to prevent undue weight from being given to moral opinions that are inconsistent with the avowed moral commitments comprising true constitutional morality. 
Waluchow's appeal to a form of overlapping consensus is controversial, as we see when several respondents question his assertion that Canadians cannot commit themselves to the right to equality while denying the legitimacy of samesex marriage. Judges practising a common law practice of judicial review do not decide such cases on the basis of their own subjective morality, but rather develop and defend a description of true constitutional morality, one which any particular judge may actually disagree with on particular issues. It is here that Stoljar pushes the argument and model further: sometimes the moral positions the courts should disqualify are failings due not to epistemic error - in which cases a sincere moral agent could be enlightened by the discovery of inconsistent moral propositions within their own thinking, whence they move on to correct those proposition by avowing a better account account of their true moral commitments (namely, it would seem, the one offered by the courts) - but rather because of substantive moral errors, where those moral agents in error are persuaded or forced to accept the moral commitments which judges think they ought to have even if they already avow contrary commitments.

And so Stoljar has us consider the Charkaoui case, whereby the Supreme Court of Canada rejected the detention of foreign nationals by means of security certificates as an unjustified violation of the Charter right to life, liberty, and security of person. (120) Unlike the situation during the Second World War where fear and racial prejudice allowed Canadians to put into reprehensible practice, with dire consequences, the incorrect moral opinion that Japanese Canadians should be placed in internment camps for the sake of national security, it is not prima facie unreasonable for a moral agent to conclude that security certificates in some limited circumstances may be justified legal instruments. I, for instance, find security certificates to be a contemptible thing, but I cannot claim that no reasonable defence of them exists, such as a defence based on a 
necessary balance between legal protections and national security. While the internment of Japanese Canadian en masse was and is objectively wrong (contrary to the moral opinions of many Canadians at the time), had the Charkaoui case gone the other way, I would be unwilling to assume that the mistake is due entirely to the epistemic disabilities brought about by fear and prejudice.

If, then, there are instances where moral commitments may be reasonable but contrary to constitutional morality, as the Charkaoui case appears to demonstrate (and for which same-sex marriage may provide another example), then in some instances the courts are not following a descriptive methodology but rather a prescriptive/constructive/ameliorative one: they are telling citizens what their moral commitments ought to be in the face of contrary reasonable moral commitments. Stoljar makes a strong case for a marked tension in Waluchow's account: "His notion of constitutional morality and the accompanying examples presuppose the descriptive model; whereas the common law model of reasoning that he endorses presupposes the constructive model." (121)

From the concrete example, Stoljar moves on to consider two versions of "[t]he 'critical examination' test of authenticity”. (123) The first, procedural version demands only that epistemic conditions be satisfied. It, however, leaves open the possibility of genuine moral disagreement which is not reducible to epistemic error. The second version of the test adds a moral condition. It, however, moves beyond a descriptive methodology of ascertaining constitutional morality and posits, instead, a prescriptive, constructive methodology. If Stoljar is correct in claiming that Waluchow's theory requires the second version, then she is also correct when claiming that "this will undermine Waluchow's purely procedural conception of democratic self-governance." (123) After analyzing Waluchow's argument in light of the supposed need for the second version of the test, Stoljar finds more similarities between living-tree constitutionalism and 
Ronald Dworkin's account of judicial review and law more generally. In the end, Stoljar is willing to support judicial review, but along the way to that decision she makes considerable modifications to Waluchow's generally cautious theory of judicial review and its attendant concepts.

Struchiner and Shecaira also find the notion of true community morality, as described by Waluchow, to be problematic. They worry about this cornerstone of Waluchow's argument insofar as the cornerstone itself rests upon a constestable assumption about modern societies. The true morality of communities may not be capable of providing sufficient guidance to judges, thus resulting in rampant judicial discretion.

First raising issues with the scope of the reflective equilibrium upon which Waluchow relies, Struchiner and Shecaira note that a narrow reflective equilibrium focuses on moral commitments may obscure or ignore aspects of the community which merit consideration, such as its sociological, psychological, and metaphysical beliefs. (137) They also question Waluchow's claim that sufficient uniformity exists in a sufficient number of cases as to make the discovery of true community morality possible. Accepting that consensus often exists, they wonder why more concrete examples are not given. As for the one detailed discussion of a concrete example - same-sex marriage- Struchiner and Shecaira are unconvinced and raise similar concerns to those of Stoljar. In short, Waluchow purports to demand only reasonable moral opinions, but is it not the case that contrary moral opinions may nonetheless be reasonable ones? And perhaps more than one set of coherent moral opinions may exist such that, as regards a particular issues, they differ from each other?

If coherent, reasonable moral positions may exist within a society - a plausible claim given the nature of many modern societies today - then something more than moral reasonableness and coherence must be at work when livingtree practices of judicial review choose between competing 
legal determinations. Of course, while one might suggest that the need to ensure coherence between moral opinions in current play and past legal decisions renders indeterminacy very rare indeed - recall that Waluchow's notion of true constitutional morality is the one which offers the best explanation of the legal practices and moral commitments of the community - there may be cases where the indeterminacy is as serious as the issue at bar. Even if a coherence criterion works, Struchiner and Shecaira note, it leaves open the question of which element of morality should be revised: the moral opinion (e.g. against same-sex marriage) or some other commitment (e.g. equality before and under the law). To determine which revision is best amounts to making a substantive moral pronouncement beyond the authority of judges: "To elect certain convictions as non-revisable would be to, arbitrarily, transform a coherence model of reasoning into a foundationalist one wherein the relevant foundations are chosen not by the community but by the judge!." (142)

All in all, the various responses to Waluchow's book constitute a lively series of critical replies to an important work. Readers must make their own determinations of the worth of living-true constitutionalism, but in any event these articles will help that model, whether it be monster of benefactor, move out of the shade and into the clear light of day. 